\title{
A Letter from a Dancer of Boubastis
}

\author{
With plate 23 \\ Willy Clarysse (Leuven) and Pieter J. Sijpesteijn (Amsterdam)
}

The present letter was found during the excavations of the University of Michigan at Karanis for the season of 1925-1926, in the structure 25-248A. Two other papyri found in the same area were of Roman date (P. Mich. VI 416 and VIII 521; inlormation by P. van Minnen). The papyrus preserves the top of a Ptolemaic letter or hypomnema, consisting almost entirely of polite phrases. The main interest of the text is that it was sent by a female somphis, clearly the Greek transcription of an Egyptian word. In our view somphis renders Egyptian thf "temple dancer". The formulas used are typical of the Egyptian (or "Oriental") epistolary style and may show that the writer of the text belonged to the native priestly milieu.

We thank Ludwig Koenen for his kind permission to publish this text here.

$13.4 \times 8.6 \mathrm{~cm}$

P. Mich. inv. no 4394a

At the left and above there is a margin of about 3 and $2 \mathrm{~cm}$. respectively. The papyrus is regularly broken off on all sides, but it is unlikely to be complete at the bottom, as the text breaks off in the middle of the introductory formulas.

\begin{tabular}{|c|c|}
\hline 1 & 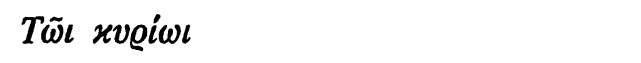 \\
\hline 2 & $\pi a \varrho a ̀ ~ \tau \tilde{\eta} \varsigma ~ \pi a \varrho a ̀ ~ \sigma o \tilde{v} \sigma \omega \hat{\omega} \mu \varphi \varepsilon \omega \zeta$. \\
\hline 3 & 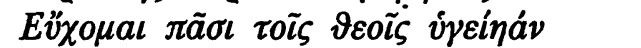 \\
\hline 4 & 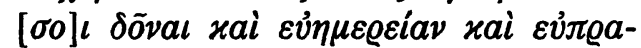 \\
\hline 5 & 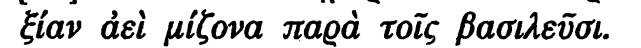 \\
\hline 6 & 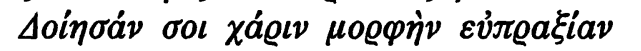 \\
\hline 7 & 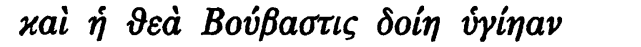 \\
\hline
\end{tabular}

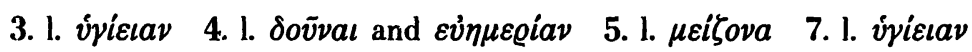

Translation

To my lord,

from your dancer. I pray to all gods that they may give you health and good fortune and ever greater success with the kings, may they give you favour and standing and success; and may the goddess Boubastis give you health - - -

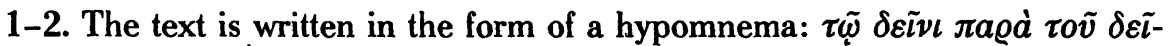
vos. The allocution $\tau \tilde{\omega} \iota \varkappa v \varrho i \omega \iota$ without a following personal name, is strange. A 


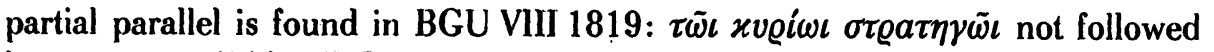
by any name (60/59 B.C.) and in P. Teb. I 165, a draft of a letter addressed $\tau \tilde{\omega} \iota$

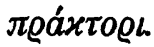

2. We have translated $\dot{\eta} \pi a \varrho a ́$ бoṽ $\sigma \tilde{\omega} \mu \varphi \iota \varsigma$ as "your dancer", but the use of

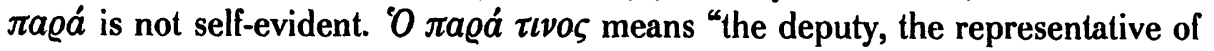
somebody", but is not usually followed by a title.

2. The title $\sigma \tilde{\omega} \mu \varphi \iota \varsigma$ is thus far attested in the following texts ${ }^{1}$ )

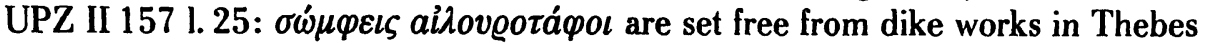
in 241 B.C.

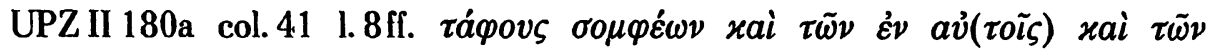

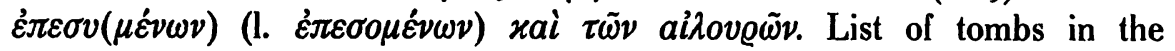
Memnoneia dated 113 B.C.

P. Heid. IV 327 (= VBP 86; wrongly cited among the geographical names in A. Calderini-S. Daris, Dizionario Geografico IV, p. 328): contract of apprentice-

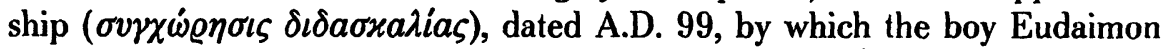
will receive instruction in the $\sigma \omega \mu \varphi \iota a x \dot{\eta}[\tau \dot{\varepsilon} \chi \nu \eta]$. The activity is not specified. SB V 7612 = P. Med. I 60, similar contract of apprenticeship from the 2 nd cent. A.D. The text is linked to the preceding one by the editor of P. Heid. IV 327. The reading $\tau \dot{\eta} \nu \sigma \omega \mu \varphi 0\left[-\ldots\right.$ - $\sigma^{2} \varrho \alpha \sigma i a v$ is certain, as can be seen on the photograph in O. Montevecchi, La Papirologia, Tav. 62. The interpretation therefore remains doubtful.

To these may be added:

CPR XIII 41.210 , where the editor's reading $\Theta \varepsilon \varrho \omega \tilde{v} \Sigma \varsigma \eta \mu \varphi \iota \varsigma$ should be corrected to $\Theta \varepsilon \varrho \tilde{\omega} v \varsigma \sigma \tilde{\omega} \mu \varphi \iota \varsigma$. Therous is a female somphis in the Fayum villa Trikomia in the second half of the third cent. B.C.

P. Athens-Trier ined. 11. 32-44 and 1.373: this is a population list from the Fayum, dating from the second century B.C. and mentioning one female somphis between the isionomoi and the theagoi of Souchos ${ }^{2}$ ). Although the order of occupations in this kind of lists is very free, this position suggests a priestly function.

P. Sorb. ined. inv. 211 l.92: in this third century B.C. list of occupations for seven villages in the division of Themistos ${ }^{3}$ ) two male sompheis and an unknown number of females are attested in two of the seven villages. The sompheis

1) The word is not found in Liddell-Scott-Jones, nor is it discussed by J.-L. Fournet, Les emprunts du grec à l'égyptien, Bull. Soc. Ling. Paris 84 (1989), pp. 55-80, the most recent survey of Egyptian loan-words in Greek. It would fit his category 4 "vocabulaire du clerge" (p. 77).

2) The Trier part of the text was mentioned by R. Scholl in ZPE 67 (1987), p. 111 and Enchoria 16 (1988), p. 135. Fragments of the same papyrus are preserved in Athens and the whole register will be published by R. Scholl, B. G. Mandilaras and W. Clarysse in Counting the People (Collectanea Hellenistica 3) as no. 26.

${ }^{3}$ ) The text will be published by W. Clarysse and D. J. Thompson in Counting the People (Collectanea Hellenistica 3) as no. 3. For a first introduction to this complicated text, see W. Clarysse, Proceedings of the Fifth International Conference for Demotists, Pisa 4-8 September 1993 EVO 17 (1994), pp. 69-77. 


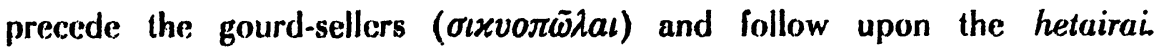
Again the place immediately after the prostitutes may be significant.

The word $\sigma \bar{\omega} \mu \varphi \iota \varsigma$ is clearly a Creck transcription of an Egyptian occupation or title. In UP\% II 157 and 180 there appears to be a link with the burial of holy cats and for that reason D. Hagedorn in his commentary on P. Heid. IV 327 considered the $\sigma \omega \mu \varphi \iota a x \eta \dot{\gamma} \tau \dot{x} \chi \eta \eta$ as part of the mummification business. The Michigan text shows that the link is not with the dead cats, but with the cat goddess Boubastis, and therefore also with the living cats.

For that reason we identify the word as the transcription of Egyptian $\operatorname{tnf}$ "the dancer"'). Boubastis was the goddess of love, but also of music, dancing and rejoicing. See the description of her festival in Herodotos II 60, where dancing

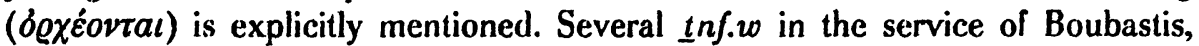
found in hieroglyphic documents, were listed by Quaegebeur and Rammant-Peeters ${ }^{5}$ ). The link with the cats is indirect: since dancers belonged to Boubastis and the cat was the sacred animal of this goddess, it was only natural that dancers and cats could be buried in the same tomb. This is, moreover, confirmed by a demotic papyrus belonging to the same choachytes' archive as UPZ II 180a, cited above: in P. Brussels dem. 5 col. 2 II. 12-14, Spiegelberg reads: $t 3$ s.t $n$ P3y-pc p3 tnf hnc n3 nty htp irm=w hnc p3 c-htp n n3 imy(.w), i.e. "the tomb of Pipes the dancer and those who rest there and the resting-place of the cats ${ }^{36}$ ). The only text that does not at first sight fit the picture is P. Heid. IV 327: one does not really expect a contract of apprenticeship for a temple dancer. But as this text is the only one of the Roman period, the sompheis may by that time have lost their link with the temples and have become professional dancers. If this is accepted there is a good parallel for the Heidelberg papyrus in the contract of apprenticeship for a musician BGU IV 1125, recently republished by A. Bélis-D. Delattre, A propos d'un contrat d'apprentissage d'aulète, Papyrologica Lupiensia 2 (1993), pp. 105-162.

As was shown by Quaegebeur ${ }^{7}$ ) the title $\underline{\operatorname{tn} f}$ was also used as a personal name. This name is found also in Greek texts, though it seems to have been rare. We have been able to identify the following instances:

- UPZ II 157 l. 58 (241 B.C.). $\Sigma \tilde{\omega} \mu \varphi \iota \varsigma$ here is neither an occupation, as

4) The hieroglyphic and demotic documentation on the title $\underline{t} n \mathrm{f}$ has been recently studied by J. Quaegebeur-A. Rammant-Peeters, Le pyramidion d'un "danseur-en-chef" de Bastet, Orientalia Lovaniensia Analecta 13.(1982) (= Studia Paulo Naster Oblata II), pp. 179-205; J. Quaegebeur, Le terme tnff(y) “danseur" en démotique, in: Grammata Demotica. Festschrift für E. Lüddeckens, Würzburg 1984, pp. 157-170. For a link between Bastet and a dancer, see also P. dem. Lille III 101 col. 5 11. 26-27.

5) J. Quaegebeur-A. Rammant-Peeters, art. cit., pp. 196-197.

6) The text is mentioned by J. Quaegebeur, Grammata Demotica, p. $159 \mathrm{C}$. The passage is also cited by P. W. Pestman, The archive of the Theban choachytes, Studia Demotica 2 (1993), p. 466, who corrects $n 3$ imj(.w) "the cats" into the personal name T3-imj "Temaus". The parallel with the Greek text shows that this correction is unnecessary.

7) J. Quaegebeur, Grammata Demotica, pp: 157-170. 
U. Wilcken and D. Hagedorn suppose, nor a geographical term, as interpreted by F. Preisigke, Wörterbuch III col. 330a, but a feminine proper name, as is clear from the following lines:

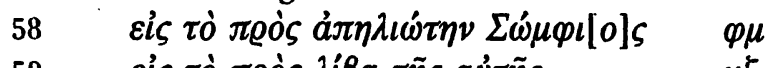

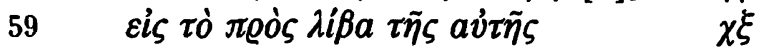

58 for the circular dike to the east of Somphis' (plot)

59 for the dike to the west of the same woman's (land)

540 (naubia)

660 (naubia)

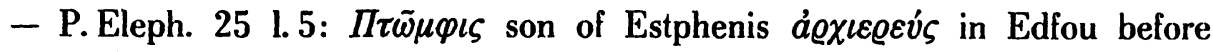
224/223 B.C. (Pros. Ptol. III 5415). As was shown by Quaegebeur (pp. 166-169), the name P3-tnf was especially popular in Edfou; it is found on the hieroglyphic stelae ${ }^{8}$ ) of some prominent Egyptian priestly families, which may have been related to Ptomphis of P. Eleph. 25. Egyptian $t$ is rendered in Greek not only by sigma, but also by tau; see J. Quaegebeur, Considérations sur le nom propre Teëphtaphônuchos, Orient. Lovan. Period. 4. (1973), pp. 85-100, esp. p. 99.

- P. Tebt. III 884 1. 39 (210 B.C.). The reading $\sum \omega \mu \psi \iota[$ is perhaps to be corrected into $\sum \tilde{\omega} \mu \varphi \iota[\varsigma]$ (cf. D. Foraboschi, Onom. Alt. Pap., p. 301 b).

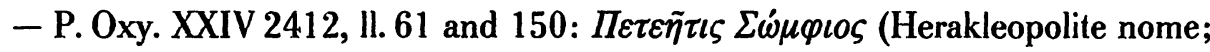
A.D. 28/29) (cf. D. Foraboschi, Onom. Alt. Pap., p. 301 b).

5. $\tau 0 \tilde{\iota} \zeta \beta a \sigma \iota \lambda \varepsilon \tilde{v} \sigma \iota:$ the plural $\beta a \sigma \iota \lambda \varepsilon \tilde{\iota}$ does not necessarily point to a coregency, but is also used for the reigning king and queen, as is clear from e.g. UPZ I 114 (150-148 B.C.; Philometor and Kleopatra) and UPZ II 162 col. 5 II. 27 and 29 (117 B.C.; Ptolemy VIII and his consorts). The plural is found from the middle of the second century onwards, the oldest example being PSAA 9 1. 6 (169/164 B.C.; the dating ought to be checked, but the text could not be found in

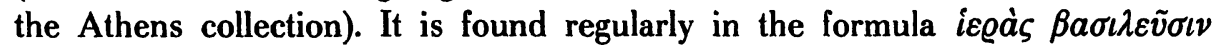

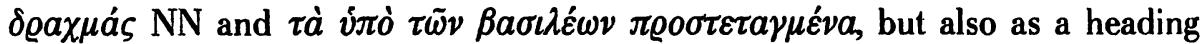

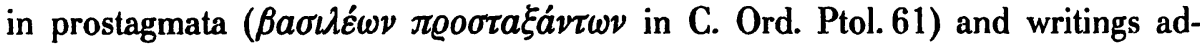
dressed to the king (UPZ I 114 l.10; UPZ 13 l.1, expanded by Wilcken as $\beta a(\sigma \iota \lambda \varepsilon \tilde{v} \sigma \iota))$.

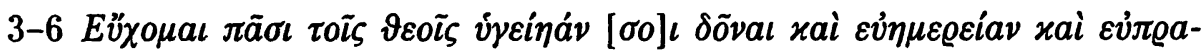

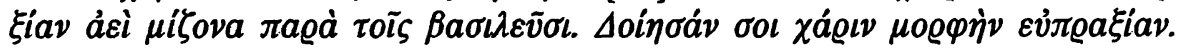

Similar pious wishes are found in letters by priests to high-ranking officials in the Ptolemaic period, though it may be noticed that $\varepsilon v i \pi \varrho a \xi i a$ is an addendum to the papyrological vocabulary. We have listed parallel passages here in chronological order.

Pap. Lugd.-Bat. XX 50 (letter of the priests of Aphrodite-Hesis-Isis to the dioe-

8) See P. Munro, Die spätägyptischen Totenstelen, Aegyptol. Forsch. 25 (1973), p. 248 (St. Kairo 22002; Saite period); p. 250 (Kairo 22013; Ptolemaic period) and p. 251 (Philip 30; Ptolemaic period; for the reading P3-thnf instead of P3-dd 3 , see H. De MeulenareL. Limme-J. Quaegebeur, Index et Addenda à P. Munro, Spätägyptische Totenstelen, Brussels 1985, p. 47). 
cetes Apollonios; 257 B.C.)

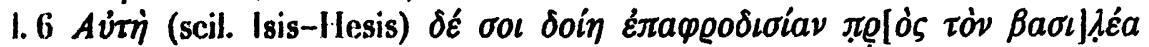

PC\% 159034 (petition of the Sarapis priest Zoilos to the dioecetes Apollonios; 257 B.C.)

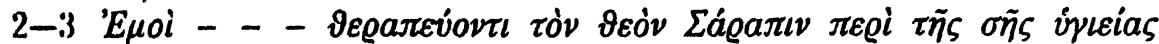

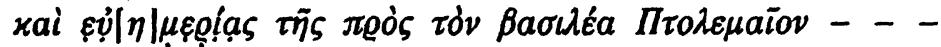

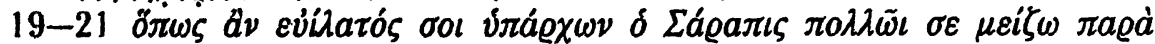

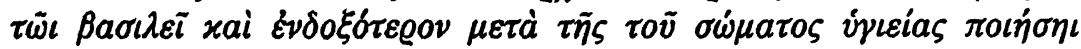

PSI V 5311.2 (letter of the priests of Astarte to Zenon, secretary of the dioecetes Apollonios; before 248 B.C.)

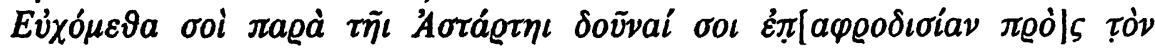
Baơliéa

P. Heid. VI 380 II. 20-21 (petition of an Egyptian priest [see II. 18-19] to a high official; 209 or 192 B.C.)

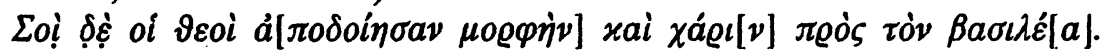

UPZ I 52 II. 25-27 and 53 II. 29-30 (petition of the katochos Ptolemaios to the hypodioecetes Sarapion; two copies of the same text with minor differences; 162 B.C.)

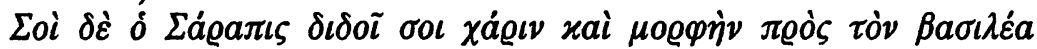

UPZ I 33-36 (hypomnemata from the katochos Ptolemaios to the dioecetes Sarapion; four copies of the same text with minor differences; 161 B.C.)

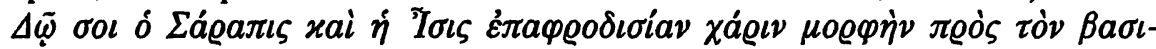

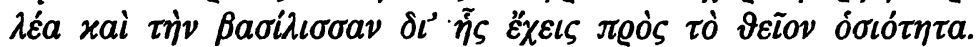

At the end of UPZ I 34-36 the formula is taken up again as follows: $\sigma o i$ yév-

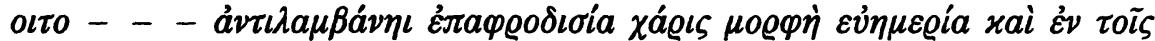

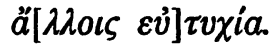

UPZ I 109 II. 9-11 (letter of the archentaphiastes Petesis to Axion; in Il. 4-7 mention is made of an audience by the king; 98 B.C.)

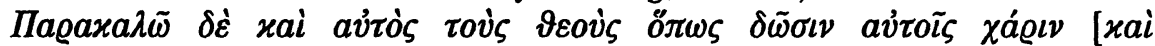

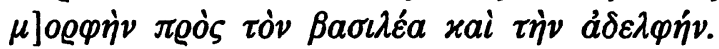

A similar formula may also be used in petitions to the king, as appears in C. Ord. Ptol. $621.13=631.9$, written by the archentaphiastes Petesis (99 B.C.):

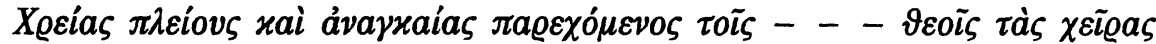

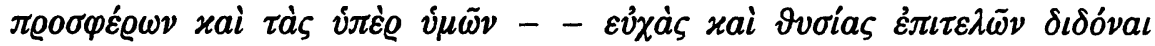

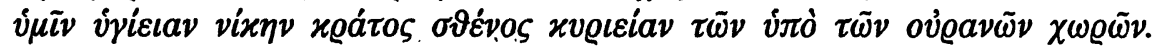
Notice the asyndetic sequence of the terms, which is also found in our text.

Among the demotic texts parallels for these polite phrases are rare. P. Loeb 6 asks the god that "he may establish the house of Teos the overseer of the fields among the favourites of pharaoh ( $h n n 3$ hsy.w $n$ Pr-c3) in eternity". The only real parallel is P. Oxf. Griffith 13, a letter of the priests of Soknopaios to the dioecetes Sarapion (150-142 B.C.), where we read "we have made obeisance (proskynema) for Sarapion the dioecetes here before Soknopaios and Isis Nepherses, who may give to you all protection of life (s3 nb cnh), who may give you a long 
and happy life, who may give you favour (hs.t), love (mr.t) dignity (šw) [before] pharaoh and Souchos in eternity." .

But there is a parallel of a much earlier period in a famous Aramaic papyrus from Elephantine of the fifth cent. B.C., a letter addressed to a highly placed offi-

$\left\{:\right.$ : cial of the Persian administration in Egypt $^{9}$ ), which proves that these kinds of phrases were common in correspondance to officials several centuries earlier and

i. that our impression that it was "oriental" rather than Greek is right, even if nearly all papyrological evidence is actually Greek. The text runs as follows in the translation of Porten and Yardeni: "To our lord Bagavahya governor of Judah, your servants Jedaniah and his colleagues the priests who are in Elephantine the fortress. The welfare of our lord may the God of Heaven seek after abundantly at all times, and favour may He grant you before king Darius and the princes more than a thousand times, and long life may he give you, and happy and strong may you be at all times."

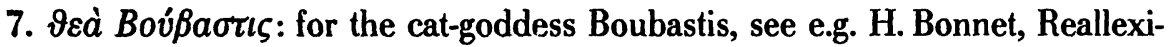
con der ägyptischen Religionsgeschichte, pp.80-82 s.v. Bastet and E. Otto in Lexikon der Ägyptologie, I coll. 628-630, s.v. Bast. For Boubastis in the GrecoRoman period, see now J. Quaegebeur, Le culte de Boubastis-Bastet et Egypte gréco-romaine, in: L. Delvaux-E. Warmenbol, Les divins chats d'Egypte (Leuven, 1991), pp. 117-127. Add the unpublished demotic texts from Tholthis, mentioned by U. Luft in EVO 17 (1994), pp. 192-194.

9) P. Porten-A. Yardeni, Textbook of Aramaic Documents from Ancient Egypt. I. Letters, Jerusalem, 1986, A 4.7 and 8, pp. 71 and 75. The edition princeps is by A. E. Cowley, Aramaic Papyri from the fifth century, Oxford 1923, no. 30. A French translation is found in P. Grelot, Documents araméens d'Egypte. Littératures anciennes du-ProcheOrient, Paris 1972, no. 102, pp.406-415. 